$$
\text { О. А. Земляний }
$$

Дніпропетровський національний університет ім. Олеся Гончара

\author{
ОСОБЛИВОСТІ НАКОПИЧЕННЯ ВАЖКИХ МЕТАЛІВ \\ ОРГАНАМИ ТА ТКАНИНАМИ МІКРОМАМАЛІЙ \\ У РІЗНИХ ЗА СТУПЕНЕМ ЗАБРУДНЕННЯ БІОГЕОЦЕНОЗАХ
}

Розглянуто особливості накопичення мікроелементів в організмі мікромамалій із різних за ступенем трансформації біогеоценозів Дніпропетровської області. Визначено показники коефіціснта накопичення в різних органах і тканинах. В екосистемах із різним рівнем і типом техногенного забруднення накопичення важких металів організмом мікромамалій відбувається неоднорідно. Визначені органи-концентратори (селезінка, серце, гонади) із переважним накопиченням важких металів, а також органи-деконцентратори (печінка, нирки, кишечник), у яких відбувається активне виведення мікроелементів. Встановлено тенденцію зниження інтенсивності накопичення мікроелементів у тварин із сильнотрансформованих біогеоценозів. Утворення спеціальних бар'єрів накопичення та виведення полютантів з організму органами-деконцентраторами свідчить про вироблення адаптивних пристосувань на фізіолого-біохімічному рівні (у першу чергу - інтенсифікація метаболізму).

\title{
А. А. Земляной
}

Днепропетровский национальный университет им. Олеся Гончара

\section{ОСОБЕННОСТИ НАКОПЛЕНИЯ ТЯЖЕЛЫХ МЕТАЛЛОВ ОРГАНАМИ И ТКАНЯМИ МИКРОМАММАЛИЙ В РАЗЛИЧНЫХ ПО УРОВНЮ ЗАГРЯЗНЕНИЯ БИОГЕОЦЕНОЗАХ}

Рассмотрены особенности накопления микроэлементов в организме микромаммалий из различных по степени трансформации биогеоценозов Днепропетровской области. Определены показатели коэффициента накопления в различных органах и тканях. В различных экосистемах с разным уровнем и видом техногенного загрязнения накопление тяжелых металлов организмом микромаммалий происходит неоднородно. Определены органы-концентраторы (селезенка, сердце, гонады) с преимущественным накоплением тяжелых металлов, а также органы-деконцентраторы (печень, почки, кишечник), в которых происходит активное выведение микроэлементов. Установлена тенденция снижения интенсивности накопления микроэлементов у животных из сильнотрансформированных биогеоценозов. Образование специальных барьеров накопления и выведения полютантов из организма органами-деконцентраторами свидетельствует о выработке адаптивных приспособлений на физиолого-биохимическом уровне (в первую очередь - интенсификация метаболизма).

$$
\text { O. A. Zemliany }
$$

Oles Gonchar Dnipropetrovsk National University

\section{FEATURES OF HEAVY METALS ACCUMULATION IN SMALL MAMMALS' ORGANS AND TISIUS IN BIOGEOCENOSES OF DIFFERENT LEVEL CONTAMINATION}

Microelements accumulation features are considered in micromammals' organism taken from different degrees transformation biogeocoenosis of Dnipropetrovs'k region. Coefficients of accumulation are 
defined in different organs and tissues. Accumulation of heavy metals in the micromammals' organism in different ecosystems, with a different technogenic contamination is heterogeneous. Organs which defined as concentrators are spleen, heart and gonads. They have primary accumulation of heavy metals. Organsdeconcentrators are those which have active extraction of microelements (liver, kidneysand and intestine). Tendency to the decline of microelements accumulation intensity in animals from strongly transformed biogeocoenosis are stated. Formation of the special barriers of accumulation and excretion from organism by organs-deconcentrators testifies to making an adaptive mechanism at the level of physiology-biochemical processes and, first of all, the metabolism intensification.

\section{Вступ}

Одне з актуальних завдань екології - оцінка накопичення важких металів у компонентах навколишнього середовища. Ця проблема пов'язана з інтенсифікацією проникнення полютантів у різні елементи біогеоценозів. Така проблема важлива для України в цілому i, особливо, для Придніпровського промислового регіону, де спостерігається значне надходження важких металів до навколишнього середовища.

Спостерігається прогресуюче насичення біосфери важкими металами. У результаті виробничої діяльності на окремих ділянках суходолу виникають досить значні концентрації металів. Протягом року розсіюється понад 25 \% річної продукції заліза. Інші метали розсіюються ще енергійніше: розсіювання ртуті та свинцю складає 80-90 \% їх річного виробництва [3].

Факт підвищення вмісту токсичних елементів під впливом забруднення середовища існування безперечний. Середні концентрації металів вищі у звірків «забруднених зон», особливо в органах і тканинах переважного депонування. Як показують численні дослідження, підвищення вмісту токсичних елементів у зовнішньому середовищі, i, насамперед, у рослинності, неминуче веде до підвищених концентрацій цих елементів в організмах ссавців [10-15]. Це відбувається в результаті активного проникнення мікроелементів у процесі дихання і з об’ єктами живлення. Збільшення кількості мікроелементів в організмі дрібних ссавців в умовах трансформованих біогеоценозів Придніпровського регіону встановлено в ході наших робіт [4-6].

Специфіка вмісту та накопичення мікроелементів в організмі тварин з екосистем із різним типом і рівнем забруднення важлива та цікава для з'ясування впливу різних видів промислової діяльності на акумуляцію основних інгредієнтів забруднення в органах і тканинах, що мають різну функціональну роль. Мета досліджень - установити особливості накопичення важких металів органами та тканинами мікромамалій у різних за ступенем забруднення біогеоценозах Дніпропетровської області.

\section{Матеріал і методи досліджень}

Дослідження проводили в різних за ступенем і видом техногенного забруднення заплавних біогеоценозах Дніпропетровської області. Як «умовно чисті», фонові території використовували біогеоценози Присамарського лісового масиву та біогеоценози, розташовані на території Дніпровсько-Орільського природного заповідника (ДОПЗ). До техногенно перетворених, імпактних екосистем належать біогеоценози в районі шлаковідвалів Придніпровської теплоелектростанції (ПдТЕС); біогеоценози під впливом хімічних і металургійних підприємств м. Дніпродзержинськ (заплава р. Коноплянка); біогеоценози, що відчувають вплив шахтних розробок Західного Донбасу (на прикладі «Східної» групи шахт); біогеоценози в районі видобутку марганцевої руди м. Орджонікідзе; біогеоценози під впливом видобутку та переробки уранової руди та поліметалів м. Жовті Води та біогеоценози під впливом видобутку та переробки залізної руди м. Кривий Ріг. 
Як об’єкт досліджень вибрано лісову мишу (Silvaemus sylvaticus L., 1758) - фоновий вид, що живе у більшості досліджених біогеоценозів. Виловлювали мікромамалій стандартним методом за допомогою давилок Геро. Для аналізу використовували дані щодо вмісту мікроелементів в організмі дорослих особин. Уміст мікроелементів в органах і тканинах тварин і грунті визначали за допомогою атомноабсорбційного спектрофотометра AAS-30 фірми Карл Цейс Йєна, Німеччина. Перерахунок проводили на суху вагу. Одним із показників, що найчіткіше відбивають процеси акумуляції мікроелементів в організмі тварин, $є$ коефіцієнт накопичення [11]. У ході роботи проведено порівняльну характеристику показників даного коефіцієнта $(K)$ різних мікроелементів в органах і тканинах лісової миші з різних за ступенем і характером забруднення місць мешкання:

$$
K=\frac{C_{1}}{C_{2}}
$$

де $C_{1}$ - вміст мікроелемента в органі або тканині, $C_{2}$ - вміст мікроелемента у грунті відповідного біогеоценозу.

\section{Результати та їх обговорення}

Техногенне забруднення зумовлює інтенсивне накопичення полютантів, різними органами та тканинами в організмі дрібних ссавців (табл.). В екосистемах із різним рівнем $\mathrm{i}$ видом техногенного забруднення накопичення важких металів організмом мікромамалій відбувається неоднорідно. Із підвищенням рівня забруднення екосистем, як правило, відзначається зменшення показників досліджуваного коефіцієнта, відбувається зниження накопичення полютантів в органах і тканинах. Це свідчить про прагнення організму тварин обмежити акумуляцію небезпечних для життєдіяльності речовин.

Таблиия

Коефіцієнт накопичення важких металів

в органах і тканинах мікромамалій із різних місць існування

\begin{tabular}{|c|c|c|c|c|c|c|c|c|c|c|c|c|c|}
\hline \multirow{2}{*}{ 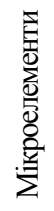 } & \multirow[b]{2}{*}{ 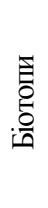 } & \multicolumn{12}{|c|}{ Органи та тканини } \\
\hline & & 羙 & 䆩 & 密 & 营 & 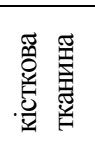 & $\begin{array}{l}\text { 总 } \\
\text { 总 } \\
\text { 焉 } \\
\text { 焉 }\end{array}$ & 覚 & 焉 & 己ृ. & 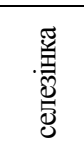 & 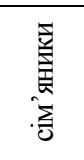 & 兽产 \\
\hline 1 & 2 & 3 & 4 & 5 & 6 & 7 & 8 & 9 & 10 & 11 & 12 & 13 & 14 \\
\hline \multirow{8}{*}{$\mathrm{Fe}$} & 1 & 3,32 & 10,64 & 8,65 & 5,14 & 12,55 & 4,25 & 5,25 & 10,57 & 13,66 & 21,71 & 4,38 & 5,57 \\
\hline & 2 & 3,09 & 4,68 & 4,31 & 10,85 & 18,37 & 3,30 & 6,02 & 11,32 & 5,42 & 11,57 & 6,88 & 15,63 \\
\hline & 3 & 2,04 & 2,36 & 2,35 & 2,41 & 9,93 & 2,64 & 0,74 & 10,31 & 14,23 & 17,63 & 7,45 & 10,47 \\
\hline & 4 & 1,00 & 0,67 & 1,10 & 1,02 & 1,37 & 0,98 & 2,02 & 1,33 & 1,57 & 2,20 & 0,99 & 0,99 \\
\hline & 5 & 3,92 & 1,91 & 3,21 & 2,62 & 5,06 & 1,83 & 1,49 & 2,35 & 4,94 & 11,80 & 0,69 & 2,13 \\
\hline & 6 & 2,93 & 6,96 & 2,71 & 0,68 & 3,66 & 1,45 & 2,42 & 5,10 & 9,03 & 5,24 & 2,04 & 0,92 \\
\hline & 7 & 1,26 & 1,79 & 1,10 & & 2,27 & 0,6 & 2,33 & 1,09 & 6,78 & 3,85 & 2,25 & 0,00 \\
\hline & 8 & 1,38 & 1,92 & 1,49 & & 4,99 & 0,55 & 1,36 & 1,05 & 0,79 & 1,52 & 2,36 & 2,46 \\
\hline \multirow{8}{*}{$M n$} & 1 & 15,09 & 4,66 & 2,71 & 3,78 & 3,91 & 2,34 & 2,56 & 2,25 & 2,60 & 7,35 & 2,94 & 0,97 \\
\hline & 2 & 9,44 & 4,67 & 3,53 & 1,19 & 8,18 & 2,77 & 2,22 & 9,63 & 8,99 & 11,85 & 4,95 & 5,31 \\
\hline & 3 & 1,36 & 1,15 & 0,48 & 0,56 & 2,75 & 1,06 & 1,19 & 2,02 & 2,88 & 8,15 & 5,14 & 0,42 \\
\hline & 4 & 1,36 & 1,17 & 2,78 & 0,88 & 3,46 & 2,33 & 3,56 & 5,76 & 4,36 & 11,00 & 5,67 & 2,60 \\
\hline & 5 & 0,57 & 0,35 & 0,25 & 0,16 & 0,52 & 0,21 & 0,30 & 0,31 & 0,47 & 0,81 & 0,33 & 0,55 \\
\hline & 6 & 0,28 & 0,83 & 0,73 & 0,35 & 0,84 & 0,80 & 0,42 & 0,49 & 1,32 & 1,85 & 0,92 & 0,23 \\
\hline & 7 & 2,15 & 2,44 & 0,00 & 0,46 & 0,79 & 0,37 & 1,11 & 0,48 & 5,65 & 2,93 & 0,36 & 0,00 \\
\hline & 8 & 1,13 & 1,98 & 0,96 & 0,47 & 4,62 & 0,59 & 1,01 & 2,64 & 1,72 & 15,86 & 25,09 & 3,57 \\
\hline
\end{tabular}

62 
Закінчення табл.

\begin{tabular}{|c|c|c|c|c|c|c|c|c|c|c|c|c|c|}
\hline 1 & 2 & 3 & 4 & 5 & 6 & 7 & 8 & 9 & 10 & 11 & 12 & 13 & 14 \\
\hline \multirow{8}{*}{$\mathrm{Cu}$} & 1 & 1,48 & 2,94 & 3,12 & 2,35 & 2,93 & 4,21 & 3,20 & 5,76 & 2,69 & 7,60 & 1,54 & 1,87 \\
\hline & 2 & 6,42 & 6,84 & 8,96 & 5,52 & 13,49 & 6,70 & 6,58 & 13,15 & 23,83 & 29,74 & 11,69 & 6,75 \\
\hline & 3 & 0,74 & 1,03 & 2,66 & 1,25 & 8,69 & 2,32 & 2,71 & 3,86 & 1,86 & 4,54 & 1,02 & 13,63 \\
\hline & 4 & 0,21 & 0,14 & 0,42 & 0,11 & 0,40 & 0,27 & 1,31 & 0,43 & 0,82 & 1,54 & 0,67 & 1,13 \\
\hline & 5 & 2,79 & 1,91 & 2,59 & 1,16 & 2,42 & 1,08 & 1,32 & 1,83 & 2,96 & 8,83 & 2,05 & 1,44 \\
\hline & 6 & 0,65 & 0,86 & 0,60 & 0,24 & 1,12 & 0,60 & 0,42 & 0,80 & 0,83 & 3,35 & 1,04 & 0,42 \\
\hline & 7 & 0,52 & 1,03 & 0,44 & 0,24 & 0,88 & 0,48 & 0,30 & 0,41 & 1,66 & 2,32 & 0,68 & 0,00 \\
\hline & 8 & 0,22 & 0,28 & 0,42 & 0,12 & 0,78 & 0,22 & 0,45 & 0,34 & 0,47 & 2,34 & 0,60 & 0,79 \\
\hline \multirow{8}{*}{$Z n$} & 1 & 6,48 & 0,48 & 2,22 & 2,07 & 5,17 & 3,09 & 0,32 & 2,17 & 2,99 & 2,30 & 1,88 & 3,01 \\
\hline & 2 & 9,36 & 3,25 & 8,13 & 4,44 & 19,15 & 11,21 & 5,68 & 13,93 & 20,14 & 28,60 & 7,36 & 8,04 \\
\hline & 3 & 1,40 & 1,69 & 1,25 & 1,06 & 3,08 & 2,00 & 2,17 & 4,21 & 4,56 & 12,57 & 5,23 & 1,67 \\
\hline & 4 & 1,01 & 0,59 & 1,39 & 0,54 & 1,55 & 0,82 & 2,46 & 1,68 & 1,95 & 10,18 & 6,12 & 4,24 \\
\hline & 5 & 7,41 & 4,30 & 3,01 & 1,49 & 3,86 & 15,63 & 2,37 & 3,72 & 3,19 & 7,89 & 1,79 & 11,65 \\
\hline & 6 & 1,24 & 3,06 & 1,02 & 0,85 & 1,59 & 1,65 & 0,82 & 1,25 & 1,10 & 2,61 & 1,68 & 0,51 \\
\hline & 7 & 0,35 & 0,39 & 0,36 & 0,12 & 0,99 & 0,26 & 0,48 & 0,16 & 1,65 & 0,70 & 0,56 & 0,00 \\
\hline & 8 & 0,25 & 0,18 & 0,30 & 0,12 & 0,84 & 0,25 & 0,40 & 0,29 & 0,39 & 0,73 & 0,20 & 1,39 \\
\hline \multirow{8}{*}{$\mathrm{Ni}$} & 1 & 3,90 & 1,17 & 1,58 & 19,49 & 2,46 & 1,51 & 1,83 & 0,99 & 3,66 & 1,25 & 0,51 & 0,89 \\
\hline & 2 & 2,94 & 2,16 & 5,43 & 4,60 & 7,39 & 3,43 & 8,73 & 5,62 & 4,52 & 4,37 & 1,39 & 1,93 \\
\hline & 3 & 0,96 & 1,05 & 1,09 & 0,48 & 2,87 & 1,08 & 2,46 & 3,33 & 2,82 & 6,30 & 4,01 & 0,95 \\
\hline & 4 & 4,15 & 1,00 & 15,67 & 1,10 & 1,80 & 5,47 & 10,70 & 1,62 & 2,14 & 12,45 & 7,69 & 2,66 \\
\hline & 5 & 12,12 & 24,69 & 20,63 & 23,20 & 26,80 & 15,60 & 9,42 & 26,75 & 11,78 & 66,73 & 12,21 & 15,06 \\
\hline & 6 & 3,06 & 5,38 & 2,86 & 1,77 & 2,65 & 2,22 & 2,50 & 8,12 & 5,62 & 8,95 & 5,99 & 0,10 \\
\hline & 7 & 5,57 & 5,15 & 0,56 & 2,56 & 1,22 & 35,34 & 0,30 & 2,77 & 10,26 & 11,28 & 3,86 & 0,00 \\
\hline & 8 & 8,58 & 8,69 & 4,71 & 2,57 & 50,64 & 3,26 & 5,35 & 5,99 & 44,66 & 89,55 & 18,96 & 9,17 \\
\hline \multirow{8}{*}{$P b$} & 1 & 1,00 & 0,84 & 1,34 & 1,18 & 3,38 & 1,70 & 1,48 & 1,53 & 4,42 & 2,54 & 0,47 & 0,69 \\
\hline & 2 & 0,30 & 0,42 & 0,34 & 0,29 & 2,15 & 0,53 & 0,36 & 1,20 & 1,29 & 1,29 & 4,07 & 3,55 \\
\hline & 3 & 5,08 & 2,75 & 4,90 & 1,47 & 13,40 & 4,02 & 3,82 & 16,96 & 17,41 & 31,90 & 6,14 & 4,76 \\
\hline & 4 & 1,52 & 1,31 & 3,05 & 0,42 & 2,63 & 2,24 & 4,01 & 3,58 & 6,27 & 18,18 & 12,67 & 10,52 \\
\hline & 5 & 3,09 & 5,62 & 5,33 & 7,39 & 5,94 & 2,04 & 0,81 & 4,08 & 1,56 & 4,69 & 2,32 & 6,36 \\
\hline & 6 & 1,03 & 0,74 & 1,07 & 1,05 & 1,54 & 1,09 & 0,88 & 1,04 & 0,90 & 2,53 & 0,47 & 0,47 \\
\hline & 7 & 1,58 & 2,63 & 1,38 & 0,29 & 5,45 & 1,32 & 0,90 & 0,50 & 1,64 & 1,37 & 3,87 & 0,00 \\
\hline & 8 & 0,93 & 0,84 & 1,47 & 0,56 & 2,40 & 1,45 & 2,09 & 1,95 & 3,15 & 8,64 & 1,25 & 3,59 \\
\hline \multirow{8}{*}{$C d$} & 1 & 1,22 & 2,69 & 1,23 & 0,88 & 1,33 & 1,34 & 1,10 & 0,59 & 0,85 & 1,19 & 0,63 & 0,19 \\
\hline & 2 & 1,09 & 1,73 & 2,58 & 1,00 & 3,09 & 4,58 & 6,38 & 13,16 & 2,43 & 9,19 & 4,02 & 1,34 \\
\hline & 3 & 1,43 & 1,34 & 2,08 & 1,60 & 1,99 & 3,32 & 3,42 & 3,56 & 2,02 & 42,76 & 4,38 & 2,44 \\
\hline & 4 & 3,97 & 3,49 & 8,81 & 1,17 & 10,19 & 6,27 & 18,18 & 13,91 & 24,56 & 61,65 & 26,70 & 46,88 \\
\hline & 5 & 10,51 & 16,03 & 18,77 & 13,38 & 23,75 & 7,75 & 4,08 & 18,04 & 11,73 & 37,53 & 11,36 & 2,41 \\
\hline & 6 & 3,08 & 2,45 & 3,83 & 4,18 & 4,79 & 2,66 & 2,43 & 1,73 & 0,62 & 0,54 & 0,95 & 0,04 \\
\hline & 7 & 2,89 & 2,29 & 2,52 & 0,82 & 4,49 & 1,26 & 2,45 & 2,34 & 4,83 & 10,74 & 3,79 & 0,00 \\
\hline & 8 & 1,05 & 1,01 & 0,86 & 0,63 & 2,91 & 0,76 & 0,82 & 1,79 & 0,86 & 2,88 & 0,73 & 1,11 \\
\hline
\end{tabular}

Примітки: 1 - біогеценози Присамарського лісового масиву, 2 - біогеоценози, розташовані на території ДОП3, 3 - біогеоценози в районі шлаковідвалів ПдТЕС, 4 - біогеоценози, що перебувають під впливом шахтних розробок Західного Донбасу, 5 - біогеоценози в районі видобутку марганцевої руди м. Орджонікідзе, 6 - біогеоценози під впливом видобутку та переробки уранової руди та поліметалів м. Жовті Води, 7 - біогеоценози під впливом видобутку та переробки залізної руди м. Кривий Ріг, 8 - біогеоценози під впливом хімічних і металургійних підприємств м. Дніпродзержинськ (заплава р. Коноплянка).

Різні органи та їх системи за ступенем накопичення важких металів можна поділити на мікроконцентратори з рисами деконцентраторів 3 активним виведенням інгредієнтів забруднення (печінка, нирки, кишечник) і на концентратори з поступовим накопиченням і зниженням виведення мікроелементів (селезінка, серце, гонади). Акумуляція небезпечних токсикантів у гонадах тварин досить негативно впливає як на нор- 
мальне функціонування даної системи, так і на відтворення популяції в цілому. Це веде до зниження показників плідності у тварин із сильнозабруднених екосистем.

Рівні накопичення важких металів у подібних умовах різні, не мають прямої залежності від їх вмісту в середовищі мешкання. Це зумовлюється як інтенсивністю метаболізму, так і особливістю самих металів, їх синергічністю та антогонізмом.

Для того, щоб протистояти надлишковому надходженню важких металів в організм, тварини та рослини мають у своєму розпорядженні систему захисних реакцій і механізмів, вироблених у процесі еволюції, а також у відповідь на зміну середовища мешкання. При надходженні важких металів із грунту в рослини перший бар'єр на їх шляху - це коренева система. Надлишкова акумуляція металів обмежується вибірковою здатністю кореневого поглинання стосовно визначених елементів [2].

При незначному вмісті хімічних елементів у грунтах рослини поглинають усі доступні для них форми сполук. При високих концентраціях спостерігається насичення хімічним елементом: кількість у рослинах може залишатися на визначеному рівні або навіть знижуватися при подальшому збільшенні вмісту елемента у грунті [1]. Лінійна залежність акумуляції металів у системі «грунт - рослина» спостерігається тільки в діапазоні малих концентрацій мікроелементів у середовищі. При високих концентраціях спостерігається зворотна залежність - чим вищий уміст елемента в середовищі, тим нижчий ступінь його поглинання [8].

Проведені дослідження установили аналогічні тенденції. При збільшенні ступеня трансформації екосистем відбувається зниження інтенсивності накопичення мікроелементів у різних органах і тканинах. Причиною цього може бути як існування своєрідного «бар'єру» на рівні кишково-шлункового тракту, який не дозволяє проникати в організм усьому обсягу мікроелементів, що міститься в навколишньому середовищі [9], так і інтенсифікація виведення органами виділителями (кишечником і нирками) мікроелементів з організму при їх значному надходженні. Усе це дозволяє підтримувати вміст мікроелементів в організмі на рівні, що не спричиняє незворотних змін.

Як правило, виявляються межі накопичення важких металів організмом тварин. На рівні шлунково-кишкового тракту утворюється своєрідний бар'єр, що перешкоджає накопиченню полютантів вище визначеної межі незалежно від їх концентрації в середовищі. Це дозволяє тваринам існувати в умовах досить значних концентрацій токсичних елементів у навколишньому середовищі. Утворення спеціальних бар'єрів накопичення і виведення полютантів 3 організму органами-деконцентраторами свідчить про вироблення адаптивних пристосувань на рівні фізіолого-біохімічних процесів організму й, у першу чергу, підвищення інтенсифікації метаболізму, що дозволяє виживати в умовах трансформації біогеоценозів.

\section{Висновки}

Техногенне забруднення зумовлює інтенсивне накопичення полютантів різними органами та тканинами організмів дрібних ссавців. Найінтенсивніше накопичення важких металів відмічається в селезінці, серці та кістковій тканині, менш інтенсивне у печінці, шкірі та м'язовій тканині. Найбільший індекс накопичення в умовах техногенного забруднення відмічається в органах, що характеризуються високим рівнем метаболізму та беруть участь в адаптаційному процесі (селезінка). Низьке накопичення полютантів у таких органах в умовах інтенсивного забруднення можна розглядати як участь їх у виведенні токсикантів (печінка, нирки). 


\section{Бібліографічні посилання}

1. Алексеев Ю. В. Тяжелые металлы в почвах и растениях. - Л. : Агропромиздат, 1987. - 142 с.

2. Власюк П. А. Микроэлементы в обмене веществ растений. - К. : Наукова думка, 1976. - 154 с.

3. Добровольский В. В. Некоторые аспекты загрязнения окружающей среды тяжелыми металлами // Биологическая роль микроэлементов. - М., 1983. - С. 44-55.

4. Земляной А. А. Сравнительная характеристика содержания биогенных микроэлементов в организме мелких млекопитающих из биогеоценозов в зоне поступления отходов угледобывающей промышленности и Присамарья / Биоэлементы. - Оренбург, 2004. - С. 115-118.

5. Земляний О. А. Біогенні мікроелементи в організмі Mus musculus із зони природної геохімічної аномалії Криворізького залізорудного бассейну // Біорізноманіття та роль тварин в екосистемах. - Д. : Вид-во ДНУ, 2009. - С. 338-339.

6. Земляний О. А. Використання мікромамалій для біоіндикації впливу джерел розсіювання емісії важких металів на природне середовище / Вісник Дніпропетр. ун-ту. Біологія. Екологія. 2009. - Т. 17. - С. 95-100.

7. Криволуцкий Д. А. Биоиндикация и экологическое нормирование / Д. А. Криволуцкий, Ф. А. Тихомиров, Е. А. Федоров // Влияние промышленных предприятий на окружающую среду. - М., 1987. - С. 18-27.

8. Кабата-Пендиас А. Микроэлементы в почвах и растениях / А. Кабата-Пендиас, Х. Пендиас. М. : Мир, 1989. - 436 с.

9. Мухачева С. В. Уровни токсических элементов и функциональная структура популяций мелких млекопитающих в условиях техногенного загрязнения (на примере рыжей полевки) / С. В. Мухачева, С. В. Безель // Экология. - 1995. - № 3. - С. 237-240.

10. Cristald M. Small mammals as biological indicators of radioactive contamination of the environment / M. Cristald, D. Mascarzon // Sci. Total Envir. - 1990. - Vol. 99. - P. 61.

11. Cadmium accumulation in herbivorous and carnivorous small mammals: Meta-analysis of field data and validation of th e bioaccumulation model optimal modeling for ecotoxicological applications / K. Veltman, M. Huijbregts, T. Hamers et al. // Environmental Toxicology. - 2009. - Vol. 26. P. 1488-1496.

12. Effects of Ash Application on Cadmium Concentration in Small Mammals / M. Lodenius, A. Soltanpour-Gargari, E. Tulisalo, H. Henttonen // Environ. Qual. - 2002. - Vol. 31, N 1. - P. 188-192.

13. Saldiva P. H. N. Animal indicators of adverse effects associated with air pollution / P. H. N. Saldiva, G. M. Bohm // Ecosystem Health. - 2002. - Vol. 4, N 4. - P. 230-235.

14. The heavy metal counter of the teeth of the bank vole (Clethrionomys glareolus) as an expoure marker of enveromental pollution in Poland / J. Appleton, K. M. Lee, K. Sawicka-Kapusta et al. // Enviromental Pollution. - 2000. - Vol. 110, N 3. - P. 441-449.

15. Further investigution of the heavy metal content of the teeth of the bank vole as an exposure inducator of enviromental pollution in Poland / J. Gdula-Argasinska, J. Appleton, K. SawickaKapusta, B. Spence // Enviromental Pollution. - 2004. - Vol. 131, N 1. - P. 71-79.

Надійшла до редколегіï 12.05.2010 